\title{
HYPOTHALAMIC TUMOR ASSOCIATED WITH ATYPICAL FORMS OF ANOREXIA NERVOSA AND DIENCEPHALIC SYNDROME
}

\author{
EUGENIO CHIPKEVITCH*, ANTONIO C.L. FERNANDES*
}

\begin{abstract}
SUMMARY - We report the case of a 10-year-old girl with a mature teratoma in the hypothalamic region. The patient presented a 2-month history of anorexia, psychic disturbances and a 37\% loss of body weight. These symptoms had led initially to a diagnosis of major depression and atypical anorexia nervosa. She also presented some signs and symptoms of diencephalic syndrome. This case illustrates the importance of considering a slow-growing mass as a rare but real possibility in the differential diagnosis of anorexia nervosa, mainly in atypical cases.
\end{abstract}

KEY WORDS: hypothalamic tumor, teratoma, anorexia nervosa, diencephalic syndrome.

Tumor hipotalâmico associado a formas atipicas de anorexia nervosa e síndrome diencefáliça.

RESUMO - Os autores relatam o caso de uma menina de 10 anos de idade com teratoma maduro na região hipotalâmica. A paciente apresentava história de 2 meses de anorexia, distúrblos psiquicos e perda de $37 \%$ de seu peso. Tais sintomas levaram inicialmente ao dígnốstico de depressão maior e anorexia nervosa atípica. Ela também apresentava alguns sinais e sintomas da sindrome diencefálica. O caso ilustra a importância de considerar tumores de crescimento lento como possibilidade rara, embora real, no diagnóstico diferencial de anorexia nervosa, particularmente em casos atipicos. cefálica.

PALAVRAS-CHAVE: tumor hipotalâmico, teratoma, anorexia nervosa, síndrome dien-

Anorexia nervosa (AN) occurs mostly in adolescent girls and its diagnosis requires the presence of: (1) weight loss leading to a weight $15 \%$ below that expected, (2) fear of obesity, (3) disturbance of body image, and (4) amenorrhea 2. Structural brain lesions have not been found in these patients, but there have been some reports $7,8,14$ of brain tumors whose initial symptoms had led to the diagnosis of AN. The best known association between cerebral tumors and emaciation in childhood is the diencephalic syndrome (DS) 1,5. DS is generally caused by gliomas in the hypothalamic (HT) and chiasmatic regions and is associated with the presence of extreme cachexia hyperactivity, cheerful affect, euphoria and alert appearance 5. Most children with DS are 6 to 18 months old, and are not anorexic 1 .

Association of DS with typical features of AN syndrome had not been described. We report a case of a 10-year-old girl with teratoma in the HT region, whose clinical presentation had initially led to the diagnosis of $A N$, and who also presented some elements of DS.

\section{CASE REPORT}

EVL, a white, middle-class 10-year-old girl, presented a 2-month history of anorexia and progressive emaciation, having lost $12 \mathrm{Kg}$ (37\% of her original weight). The anorexia had begun after the girl had witnessed a fight between her grandparents. The patient was the

*Dlvision of Adolescent Medicine, Darcy Vargas Children's Hospital (SUDS), São Pau10. Aceite: 03-agosto-1992.

Dr. Eugenio Chipkevitch - Rua Br. Jacegual 1164/113 - 04606-002 Săo Paulo SP - Brasil. 
oldest of 3 daughters. Her neuromotor development was normal, with the exception of a secondary nocturnal enuresis since 4 years of age. Her mother thought she have been drinking too much liquid since this age. She denied headache, visual disturbances or any interruption of growth. Her parents described her as having always been introverted, quiet, perfeccionist and hilgh-achiever. Her father was an alcoholic and, when drunk, arrived home aggressive, fighting with his wife. After the patient had become anorexic, he stopped drinking completely, concerned that his daughter's illness could be his fault. The girl began to eat more when fed by him. She had always been "demanding" in her eating habits, being very selective, but used to eat well. Since the onset of anorexia she often made comments about food, opening the refrigerator, showing interest in food but not eating it spontaneously. She was completely indifferent to her intense emaciation, but had never showed any desire to diet or to exercise, nor any concern as to her weight.

At physical examination, the patient was emaciated and pale. Weight $20 \mathrm{Kg}$ (below 3rd percentlle), height $132 \mathrm{~cm}$ (25th percentile, both parent's height being at the same percentile). Head circumference $50.5 \mathrm{~cm}$ (below 50 th percentile). Tanner stage $M_{2} P_{1}$. Heart rate 80, and blood pressure 70x50. The neurological examination was normal. At psychiatric exa-
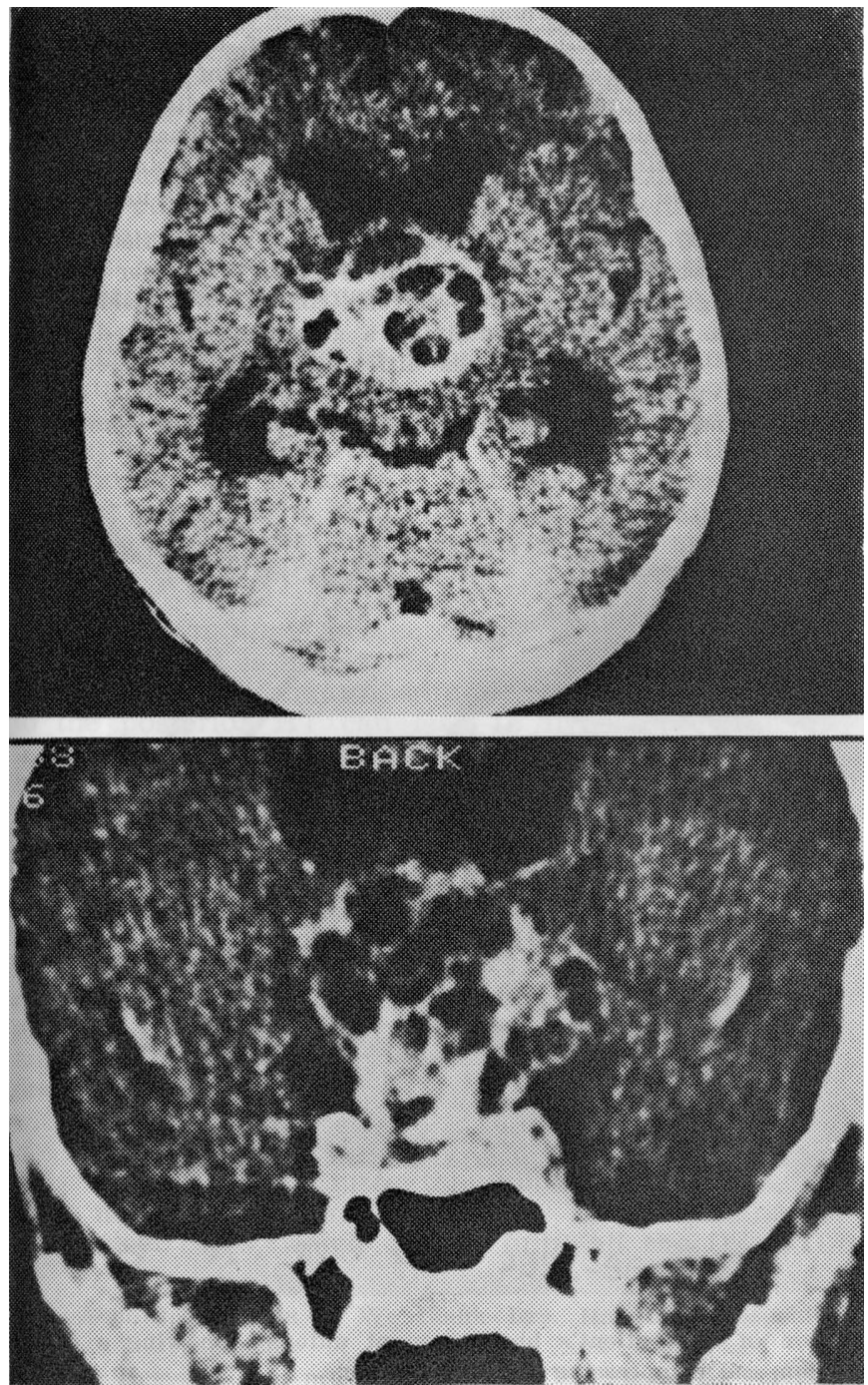

Fig. 1. Case EVL. CT scans of the patient (above, axial and below, coronal views), demonstrating a suprasellar mass. 
mination, the patient was passive, apathetic and somnolent, with minimal attention span. She showed periods of hyperactivity, waving her arms or compulsively counting numbers or objects around her. Although the patient did not met all the DSIM-III-R 2 criteria for AN, the presence of various psychodynamic elements suggested a diagnosis of atypical AN associated wth a major depression. Hemoglobin, hematocrit and blood cell count were normal, as well as serum potassium, chloride, calcium, phosporus, BUN, creatinine, glucose, and urinalysis. Magnesium (13 $\mathrm{mEq} / \mathrm{L})$ and albumin $(2.8 \mathrm{~g} / \mathrm{dL})$ were low. Serum sodium (149 $\mathrm{mFq} / \mathrm{L})$ and asmolality (302 mOsm) were slightly elevated, and urine osmolality was low (268 mOsm, after fluid restriction). Visual aculty was 0.9 for the right and 1.0 for the left. The fundus examination showed slight papilledema in the right. Skull X-ray was normal, except for a possible enlargement of the sella turcica. There were no calcifications nor erosion of the sella. CT san (Fig. 1) disclosed the presence of an expansive suprasellar lesion, irregularly oval, with cystic areas in its interior.

The patient was transferred, after 5 days, to the Neurosurgical Unit of the São Paulo University Hospital. Her general status was deteriorating, and she showed signs of organic brain syndrome. She accepted almost nothing by mouth and vomited after being fed. Her hyperkinesis aggravated, with involuntary, rhythmical, irregular movements of the extremities. The muscular strength and tonus were diminished and there were a multidirectional nystagmus and palpebral retraction. The cerebrospinal fluid examination showed 11 leucocytes, normal glucose and increased proteins $(96 \mathrm{mg} / \mathrm{dL})$. Stereotaxic blopsy of the hypothalamus showed proliferation of astrocyte-like, fusiform cells, and presence of nests of epithelial cells and corneal globes. The scarcity of material prevented a definite histological diagnosis After the blopsy, the patient's neurologtcal status deteriorated, she developed a pulmonary infection, and finally died. Unfortunately, the endocrinological study could not be completed. On admission, T3, T4 and TSH were normal and prolactine was: slightly elevated (32 $\mathrm{ng} / \mathrm{mL})$.

At necropsy, the brain weighted $1200 \mathrm{~g}$, showing e tumor protuding on the floor of the 3rd ventricle and forcing the chlasm forward. On sagittal section (Fig. 2) the tumor was encapsulated, well circumscript, measuring $3.5 \times 3.0 \mathrm{~cm}$, with petrous consistence. Inside there were hemorrhagic areas, and other areas were cystic containing a greenish coagulated liquid. On histological examination, the tumor consisted of various different kinds of tissue: cartilage, glands, respiratory and intestinal epithelium, fibrous tissue, papillary formations, smooth muscular and nervous tissue. The diagnosis was of a mature teratoma of the 3rd ventricle.

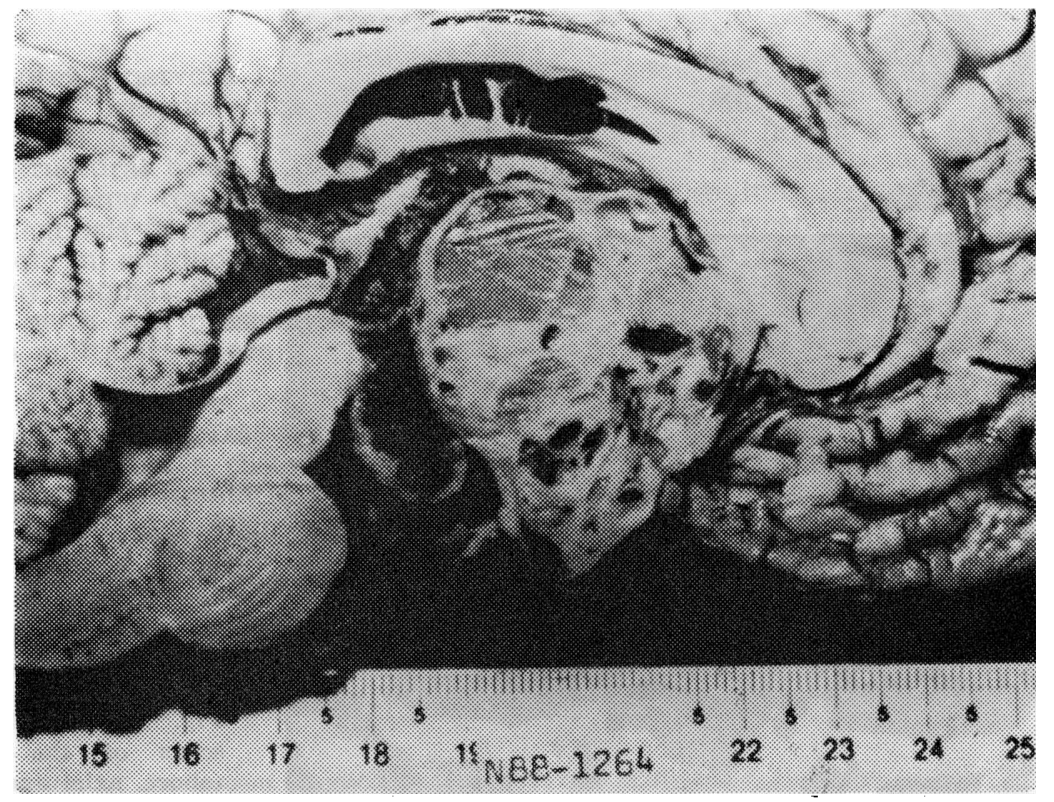

Fig. 2. Case EVL. Saggital section of the patient's brain seen at autopsy, showing a cystic tumor Invading hypothalamic region and compressing the 3 rd ventricle. 


\section{COMMENTS}

AN is generally believed to be primarily a psychogenic disorder being the concomitant HT dysfunctions attributed to starvation 4. Nevertheless, the frequent occurrence of amenorrhea prior to weight loss and the persistence of this and some other endocrine and neurochemic abnormalities after weight recovery support the possibility of a primary HT disorder 11. Although anatomic lesions of the HT have not been found in patients with this disease, some cases have been reported $7,8,14$ in which AN was associated with or suspected prior the diagnosis of a brain tumor.

Our patient presented many characteristics suggesting the diagnosis of AN. Her symptoms also fulfilled DSM-III-R criteria 2 for major depressive disorder. Depression and other psycho-affective disorders are often found to be associated with AN 12. These characteristics of our patient, associated with depression, and the absence of both distorted body image and fear of obesity, suggested an atypical AN 4 .

Our patient also presented some signs observed in the DS: hyperkinesis, nystagmus, palpebral retraction, diabetes insipidus, pallor without anemia, vomiting, hydrocephalus, papilledema and elevated concentration of cerebrospinal fluid protein 1,5. We did not consider her as having a classic DS because of her age, intense anorexia, and depression instead of euphoria. Most children with DS are euphoric and cheerful, not anorexic, and less than 3 years old 1,5. Identical tumors in older children usually manifest themselves through obesity, precocious puberty, hypogonadism, but not emaciation. However, the DS is probably a much lesser homogeneous condition that it is generally believed 5 . Some reviews have reported that about $40 \%$ of the cases were anorexic and about one-fourth were not hyperactive nor euphoric 1 .

It is interesting to note that some symptoms, such as hyperactivity and signs of autonomic imbalance, are observed both in AN and DS, perhaps due to dysfunctions in the same HT areas. Our case is curious in that it presents a diencephalic-like syndrome at this age, and that it manifests features of both AN and DS, an association that we could not find in the literature. It is also singular for being a teratoma associated with anorexia and emaciation. Emaciation was sometimes described in association with the suprasellar germinoma 9 , but not with teratoma.

The symptoms presented by our patient can be attributed to an extensive HT damage. It is known that experimental lesions of lateral HT lead to aphagia and emaciation 3 as also adipsia, finickiness and motor disturbances 13 . Damage to the posterior HT can lead to hypersomnia disturbances of conscience and apathy 6 , which were present in our patient. Her periods of hyperkinesis could be explained by the damage to the lymbic inputs to the HT 6 . Periods of hyperactivity are also observed in lateral HT syndrome 13, and stereotyped somatic movements can also be elicited in a animals by stimulation of the posterior HT 6 .

The peak occurrence of intracranial germ-cell tumors is at the age of 10-12 10. Their most usual localization is in the pineal and suprasellar region both involved in the regulation of gonadothropic activity, which increases at puberty, as does the secretion of growth hormone. This sharply defined age range and the specificity of site of origin suggest that the pubertal neuroendocrine events could activate the growth and the expression of malignant behaviour of these intracranial embryonal tumors 10 . The clinical evolution of our patient is compatible with this hypothesis.

This case illustrates the importance of considering a slow-growing brain mass as a rare but real possibility in the differential diagnosis of AN, mainly in atypical cases, which do not fulfil all the DSM-III-R 2 criteria.

Aknowledgements - We thank Drs. Hamilton Matushita and Nelio Garcia de Barros, from the Departments of Neurosurgery and Neuroradiology of the São Paulo University Clinical Hospital, for providing data on the patient's internation at their unit. 


\section{REFERENCES}

1. Addy DP, Hudson FP. Diencephalic syndrome of infantile emaciation: analysis of literature and report of further 3 cases. Arch Dis Child 1972, 47:338-343.

2. American Psychiatric Association. Diagnostic and statistical manual of mental disorders. Ed 3, rev, Washington DC: American Psychiatric Association, 1987.

3. Anand BK, Brobeck JR. Hypothalamic control of food intake in rats and cats. Yale J Biol Med 1951, 24:123-140.

4. Bruch H. Eating disorders: obesity, anorexia nervosa and the person within. New York: Basic Books, 1973.

5. Burr IM, Slonim AE, Danish RK. Diencephalic syndrome revisited. J Pediatr 1976, 88:439-441.

6. Carmel PW. Surgical syndromes of the hypothalamus. Clin Neurosurg 1980, 27:133-157.

7 Climo LH. Anorexia nervosa associated with hypothalamic tumor: the search for clinicalpathological correlations. Psychiat J Univ Ottawa 1982, 7:20-25.

8 Hollatz F, Ziolko HU. Zur Differentialdiagnose der Anorexia Nervosa. Munch Med Wschr 1976, 118:263-266.

9. Imura H, Kato $Y$, Nakai $Y$. Endocrine aspects of tumors arising from suprasellar, third ventricular regions. Progr Exp Tumor Res 1987, 30:313-324.

10. Jennings MT, Gelman R, Hochberg F. Intracranial germ-cell tumors: natural hystory and pathogenesis. J Neurosurg 1985, 63:155-167.

11. Plum F, Van Uitert $R$. Nonendocrine disease and disorders of the hypothalamus. In Reichlin S (ed): The hypothalamus. New York: Raven Press, 1978, p 415-474.

12. Schwabe AD, Lippe BM, Chang J. Anorexia nervosa. Ann Intern Med 1981, 94:371-381.

13. Teitelbaum P, Epstein AN. The lateral hypothalamic syndrome: recovery of feeding and drinking after lateral hypothalamic lesions. Psychol Rev 1962, 69:74-90.

14. Weller RA, Weller EB. Anorexia nervosa in a patient with an infiltrating tumor of the hypothalamus. Am J Psychiatry 1982, 139:824-825. 